\title{
HYDROLOGIC VULNERABILITY AND FOOD PRODUCTION: THE CASE OF JALISCO, MEXICO
}

\author{
Vulnerabilidad hídrica y producción de alimentos: el caso de Jalisco, México
}

\begin{abstract}
Fabiola Giovana Amaya Acuña ${ }^{1}$ and Arturo Curiel Ballesteros ${ }^{2 *}$
${ }^{1}$ Instituto de Investigaciones en Ecosistemas y Sustentabilidad (IIES), Universidad Nacional Autónoma de México (UNAM), Morelia 58190, Mexico. 2Centro Universitario de Ciencias Biológicas y Agropecuarias (CUCBA), Universidad de Guadalajara. Camino Ing. Ramón Padilla Sánchez \#2100, Predio Las Agujas, Zapopan, Jalisco, Mexico. Telephone: +52 (33)377711150.
\end{abstract}

*Autor para correspondencia: arturoc@ @redudg.udg.mx

\begin{abstract}
Water management and planning, even when taking into account uncertainty in the availability of water, are essential elements for reliability in food production; phenomena such as droughts and temperature increase intensified by climate change determine water supply and demand in production systems. The first step in the process of adaptation to climate change is to determine the area's vulnerability (INECC, 2012). In this paper, hydrologic vulnerability was assessed through analyzing the ratio of water supply and demand in the main sectors that use the water found in the sub-watersheds of the state of Jalisco, Mexico, recognized as one of the main producers of staple foods in the nation. This study determined that the Altos Norte region exhibited the highest hydrologic vulnerability in Jalisco, thus identifying it as a priority region with regard to climate change adaptation, in contrast to the trend scenario projecting the collapse of the system.
\end{abstract}

Key words: Water Demand, climate anomalies, resilience to climate change

\section{Resumen}

La planificación y manejo del agua, aun con el factor de incertidumbre en la disponibilidad del recurso, constituyen un elemento esencial para la seguridad en la producción de alimentos. Fenómenos como la sequía y aumento de temperatura intensificados por cambio climático condicionan los niveles de demanda y oferta hídrica en sistemas productivos. El primer paso en el proceso de adaptación al cambio climático es determinar la vulnerabilidad del territorio (INECC, 2012). En este documento, se evaluó la vulnerabilidad hídrica mediante el análisis de relación oferta y demanda hídrica de los principales sectores involucrados en el uso del agua en subcuencas hidrográficas del estado de Jalisco, México, reconocido a nivel nacional por su alta productividad de alimentos básicos. En el estudio, se identificó a la región Altos Norte con mayor vulnerabilidad hídrica en Jalisco, siendo consecuente su estatus de región prioritaria para la adaptación, en contraste al escenario tendencial que proyecta el colapso del sistema.

Palabras clave: Demanda de agua, anomalías climáticas, resiliencia al cambio climático. 


\section{Introduction}

The state of Jalisco is located in western Mexico, where the ecosystems' provisioning services are the most significant in the country as this area produces the most food in Mexico (Gobierno del Estado de Jalisco, 2017), and it is where Lake Chapala, the largest lake in the country, is found. The existence of a variety of landforms, soils and vegetation produces different climates that are rich in terms of diversity, but at the same time, increases vulnerability to climate change. Efficient water management to ensure sustained food production in the face of climate change, coupled with the direct supply of water to cities, is the most important adaptation measure, as it seeks to satisfy a most basic need of human beings, by establishing as a point of reference the vulnerability of regions and production systems. This paper establishes the main characteristics, and diagnoses the needs, of water vulnerability in Jalisco, Mexico, with the main objective of identifying priority areas for climate change adaptation measures.

\section{Methodology}

Area of study. The area of study consists of the entire state of Jalisco (Figure 1), which covers 78,588 square kilometers $\left(\mathrm{Km}^{2}\right)$, located in western Mexico between $22^{\circ} 45^{\prime}-18^{\circ} 55^{\prime}$ latitude $\mathrm{N}, 101^{\circ} 28^{\prime}-105^{\circ}$ $42^{\prime}$ longitude $\mathrm{W}$. The state's territory is part of the transitional zone between the nearctic and neotropical ecozones. In western Jalisco, an important coastal fringe borders on the Pacific Ocean (Halffter, 2003; INEGI, 2010).

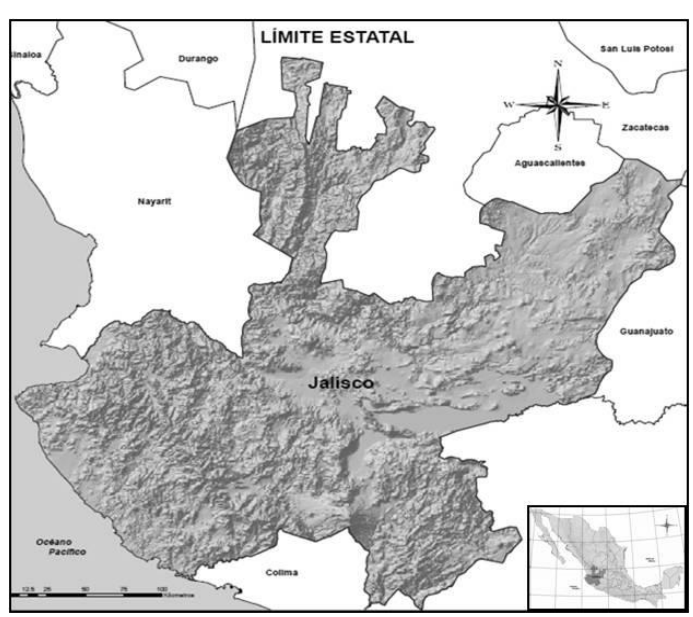

Figure 1. Jalisco Boundaries. Source: CEA Jalisco, 2013.

\section{Hydrologic vulnerability}

This paper assesses hydrologic vulnerability using the sub-watersheds of the state of Jalisco as zoning units, on a scale of 1:250 000 .

We considered only those subwatersheds with significant input, i.e., that its tributaries contribute water to Jalisco's principal watersheds, such that we only included those that are second-order streams or higher, according to Horton's classification (1945). To determine such sub-watersheds, we used the IITEJ (Jalisco State Land Information System, 2012) vector dataset for Jalisco, the hydrographic network of Jalisco at a 1:50 000 scale and the sub-watersheds established by INEGI (2012) as published in the SIATL (Water Flow Simulator of Watersheds) website.

The vulnerability assessment required a breakdown of green and blue water, the first referring to water concentrating in soil moisture and the second, to surface water and groundwater.

The process involved identifying water vulnerability in the sub-watersheds included in the study, and the demand $v s$. supply ratio. This was undertaken using the 
concept of water vulnerability, which is the dependence of vulnerability on changes in the volume of water resources. Thus, we considered that the degree of vulnerability is directly related to how much larger demand is than actual supply. We used the equation determined by Cardona and Sarmiento (1990):

$\mathrm{V}=\mathrm{D} / \mathrm{O}$

Where:

$\mathrm{V}=$ Vulnerability.

$\mathrm{D}=$ Demand.

$\mathrm{O}=$ Supply.

\section{Demand}

The sectors considered for this study were agriculture, livestock farming and human population, grouped according to supply source (green/blue water):

- Green water: Rainfed farming.

- Blue water: Irrigation farming, livestock farming and human population.

Green water: The calculation of the demand by representative rainfed crops (> $20 \%$ of the cultivated area within the municipality), was based on the assessment of Consumptive Use (CU) defined as the amount of water the plant requires to perspire and form cell tissue, plus the water that evaporates from the soil where it grows. This was defined according to the methodology published in the Soil and Water Conservation Handbook (Colegio de Postgraduados, 1991):

$\mathrm{UC}=\mathrm{KF}$

Where:

UC: Consumptive use.

$\mathrm{K}$ : Coefficient depending on crop.

$\mathrm{F}: \sum_{i}=1$

\section{Blue water:}

- Irrigation farming: Water demand was established considering the representative crops $(\geq 20 \%$ of the cultivated area within the municipality), and based on the CU assessment using the methodology published in the Soil and Water Conservation Handbook (Colegio de Postgraduados, 1991), described in the preceding paragraph.

- Milk and beef livestock farming: We considered the estimates of annual water consumption (Mekonnen et al. 2012) by cattle for milk ( $\left.2056 \mathrm{~m}^{3} / \mathrm{y} / \mathrm{animal}\right)$ and beef (630 m3/y/animal) production, in order to establish water demand for raising cattle in each municipality.

- Human population: Annual water consumption for urban populations in the metropolitan area of Guadalajara and Puerto Vallarta was estimated according to $280 \mathrm{l} /$ day/person and, for other localities, the maximum amount recommended by the World Health Organization (WHO) to meet basic needs: 100 1/day/person (Mendoza 2012, WHO, 2003).

\section{Supply}

Green water: Green water supply was obtained from raster data for average precipitation from 1961-2000 (Ruíz, et al., 2003) and runoff by sub-watershed. The calculation was undertaken as follows:

$\mathrm{AV}=\mathrm{Pp}-\mathrm{Q}$

Where:

AV: Green water.

Pp: Precipitation.

Q: Run-off.

Blue water: two types of supplies were studied, ground and surface water. The first corresponds to annual average total recharge, that is, the sum of the volume of water entering the aquifer as vertical recharge. Surface water supply includes dams, ponds and Lake Chapala (CONAGUA, 2012).

$\mathrm{AA}=\mathrm{ASb}+\mathrm{ASp}$

Where:

AA: Blue water.

ASb: Ground water.

ASp: Surface water. 


\section{Hydrologic vulnerability categories}

Once the water demand and supply values for the state of Jalisco had been established, we applied the equation and the results were grouped into eight vulnerability categories:

\begin{tabular}{|l|l|}
\hline Vulnerability category & $\begin{array}{l}\text { Blue water } \\
\text { Demand/Supply Ratio }\end{array}$ \\
\hline 8 Extreme & $>5^{\mathrm{B}}$ and $>1^{\mathrm{G}}$ \\
\hline 7 Accute & $4-5^{\mathrm{B}}$ and $>1^{\mathrm{G}}$ \\
\hline 6 Severe & $1-3^{\mathrm{B}}$ and $>1^{\mathrm{G}}$ \\
\hline 5 High & $>1^{\mathrm{B}}$ and $<1^{\mathrm{G}}$ \\
\hline 4 Moderate & $<1^{\mathrm{B}}$ and $3-4^{\mathrm{G}}$ \\
\hline 3 Mild & $<1^{\mathrm{B}}$ and $2-3^{\mathrm{G}}$ \\
\hline 2 Low & $<1^{\mathrm{B}}$ and $1-2^{\mathrm{G}}$ \\
\hline 1 No apparent vulnerability & $<1^{\mathrm{B}}$ and $<1^{\mathrm{G}}$ \\
\hline
\end{tabular}

\section{Results}

In order to establish a territorial diagnosis based on identifying water vulnerability, as mentioned in the methodology, it was necessary to calculate water demand and supply, considering green water and blue water for agricultural, livestock and urban sectors.

Agriculture Demand. Rainfed agriculture water demand is shown on Figure 2, divided into seven categories ranging from 0 to over $1000 \mathrm{Mm}^{3}$ per year. The highest water demands of this sector are found in the sub-watersheds of the following rivers: R. Purificación, R. Tecuán, R. Cuitzmala, R. Ameca-Ixtapa, R. Ayuquila, R. Chacala, R. Tomatlán, R. Zula, R. Tuxpan, R. San Nicolás and R. Ángulo-Briseño. The only subwatershed included in the category establishing over $1,000 \mathrm{Mm}^{3}$ per year to meet the needs of the crops in the area is that of the Purificación River. In contrast, there is a low demand level in the $R$. Chico, R. Huichol, R. Huejuquilla, R. Tepetongo, R. Atengo, R. Valparaiso, R. Bolaños-Huaynamota, R. Juan, and R. Calderón subwatersheds which, according to the calculations, is under $100 \mathrm{Mm}^{3}$. 


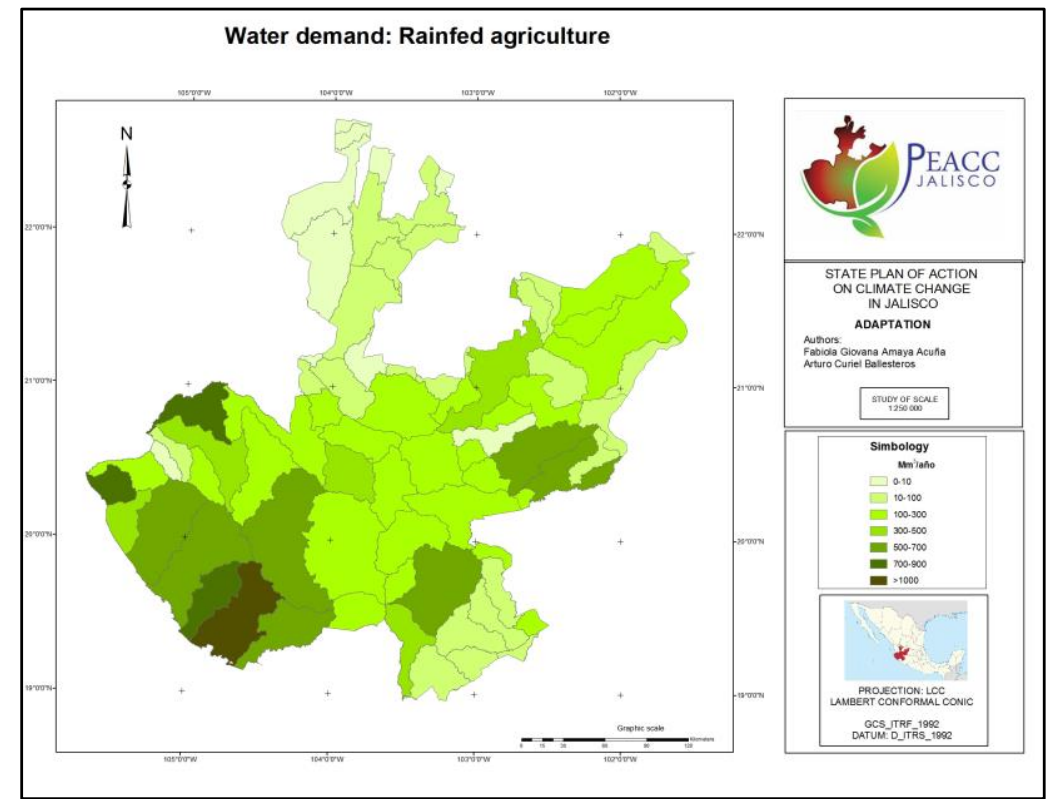

Figure 2. Rainfed agriculture (Mm3).

The irrigation farming demand shown on Figure 3 establishes that the greatest pressure for water in this sector, demanding over $100 \mathrm{Mm}^{3}$ annually, is found in the following watersheds: $R$. Tuxpan, R. Salado, R. San Miguel, R. Cocula, R. Ayuquila, R. Lagos, R. Tomatlán, and R. Encarnación.

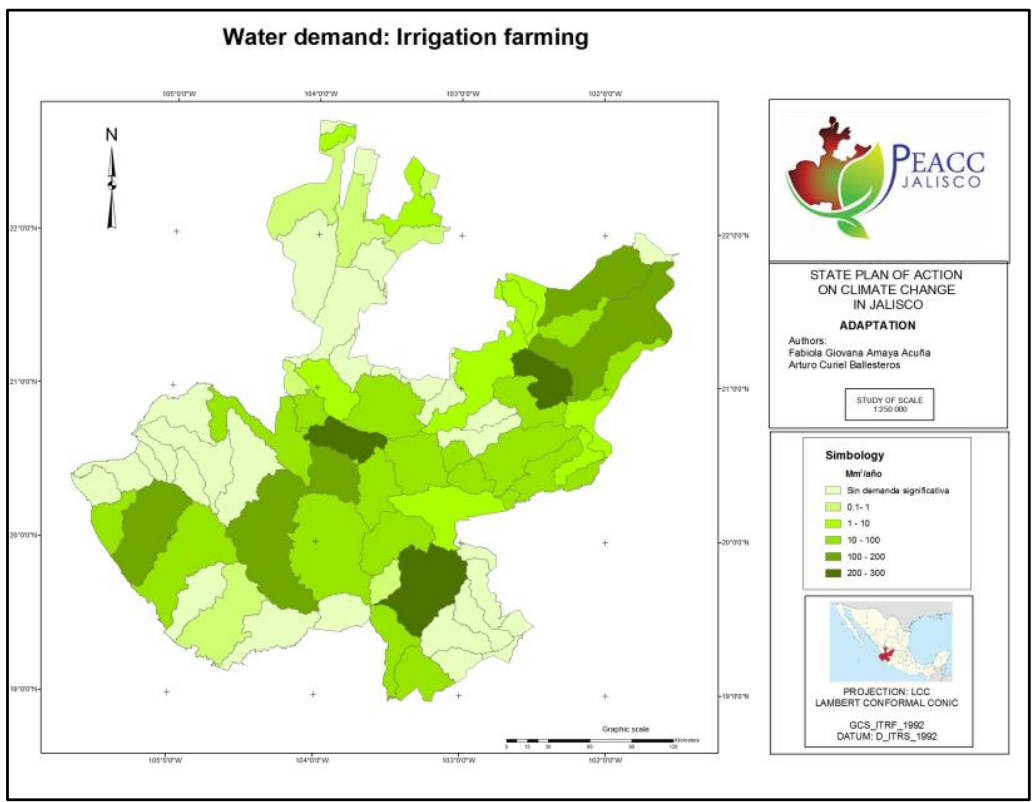

Figure 3. Irrigation farming $\left(\mathrm{Mm}^{3}\right)$.

Livestock farming demand. The greatest blue-water demand in this sector, over 100 $\mathrm{Mm}^{3}$, is found in two sub-watersheds: R. de los Lagos and R. San Miguel. They are followed by the R. Encarnación and R. Zula sub-watersheds with a demand of 83 and $74 \mathrm{Mm}^{3}$ annually, respectively. The following sub-watersheds demand over 50 $\mathrm{Mm}^{3} /$ year: R. Ayuquila, R. Verde Grande, R. Grande, R. Tepatitlán and R. Calderón (Figure 4). 


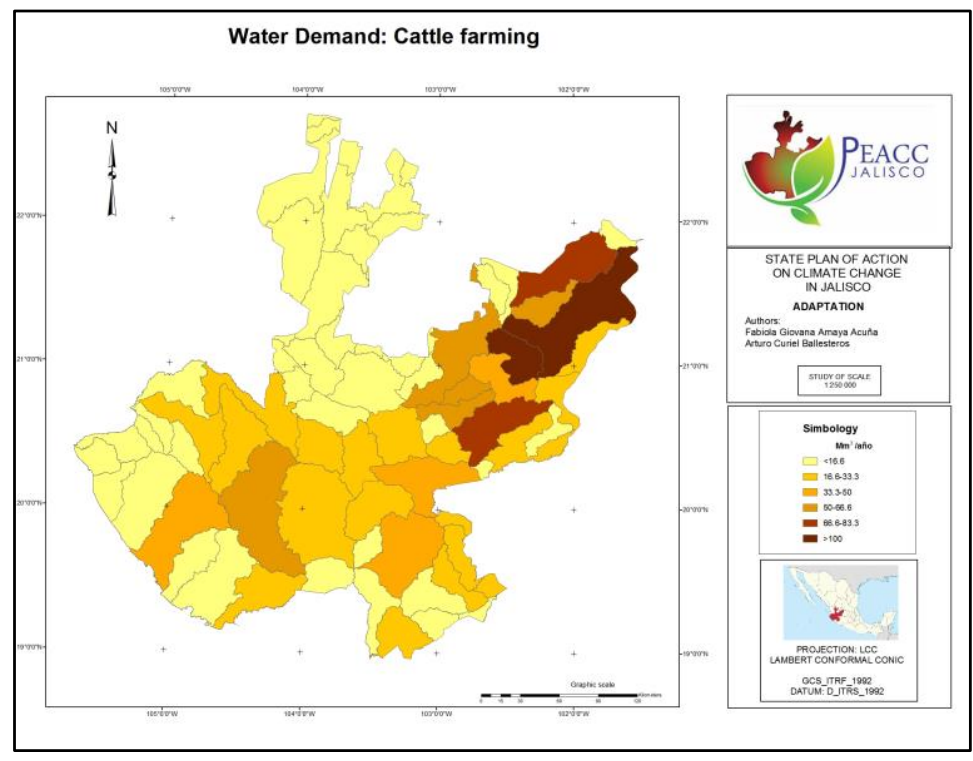

Figure 4. Cattle farming $\left(\mathrm{Mm}^{3}\right)$.

\section{Human population demand.}

The subwatersheds with the greatest annual demand in order to meet the basic needs of its human populations are: Lake Chapala $\left(260 \mathrm{Mm}^{3}\right)$ and R. Corona-R. Verde $\left(103 \mathrm{Mm}^{3}\right)$. The other units exerting pressure on this resource are $\mathrm{R}$. Calderón $\left(50 \mathrm{Mm}^{3}\right.$ ) and R. Verde- Santa Rosa Dam (42 $\left.\mathrm{Mm}^{3}\right)$, primarily to satisfy the needs of Guadalajara's Metropolitan Area.

Another subwatershed that stands out due to the pressure it exerts is R. Pitillal, where the urban areas of Puerto Vallarta are located, with a demand of $17 \mathrm{Mm}^{3}$. Elsewhere in the state, according to estimates, the demand is less than 10 $\mathrm{Mm}^{3} /$ year (Figure 5).

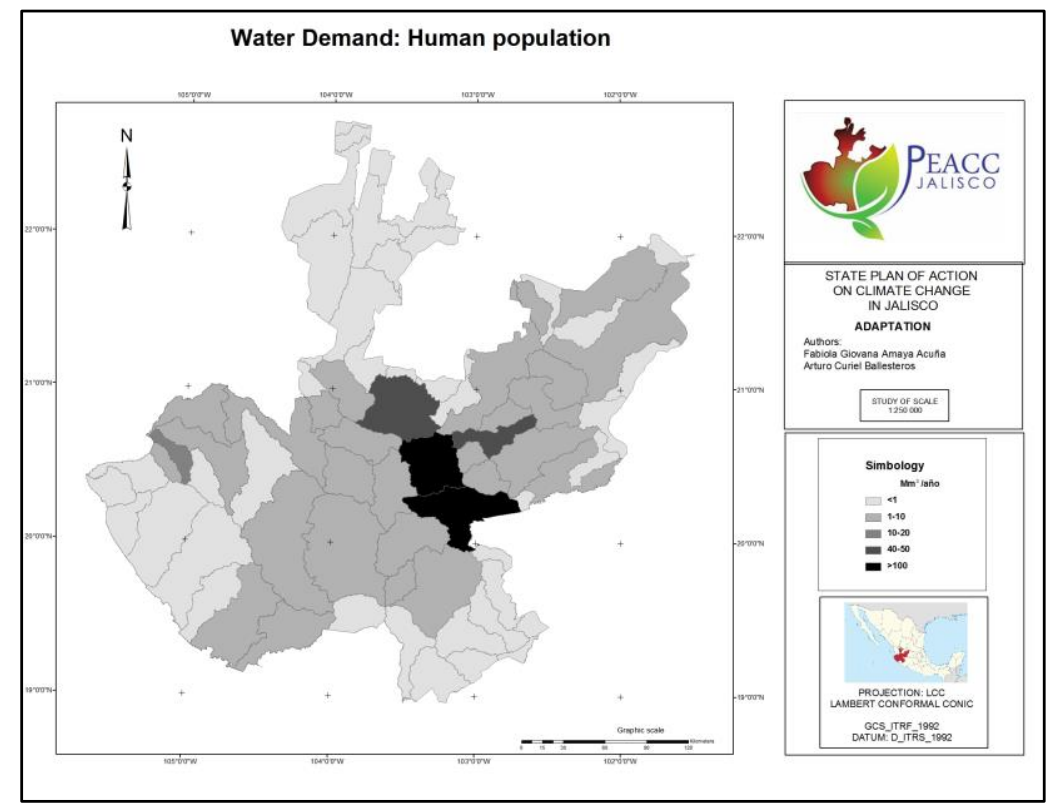

Figure 5. Human population $\left(\mathrm{Mm}^{3}\right)$. 


\section{Green-water supply.}

The subwatersheds located in the Costa Norte and Costa Sur region and the Sierra Occidental and Sierra de Amula region are those that offer the highest supply in the state per hectare; such watersheds are: R. Mismaloya and R. Tecuán, registering over $7000 \mathrm{~m}^{3} /$ ha/year.
In contrast, the Norte and Altos Norte regions' subwatersheds record the lowest supply, under $3000 \mathrm{~m}^{3} /$ ha/year. Such watersheds are: P. San Pablo, R. Bolaños Alto, R. Teocaltiche, R. Aguascalientes, R. Huejuquilla, R. Encarnación, R. Tepetongo, R. San Juan, R. Colotlán, R. Atengo and R. Valparaíso, which are shown in Figure 6 in the lightest shades.

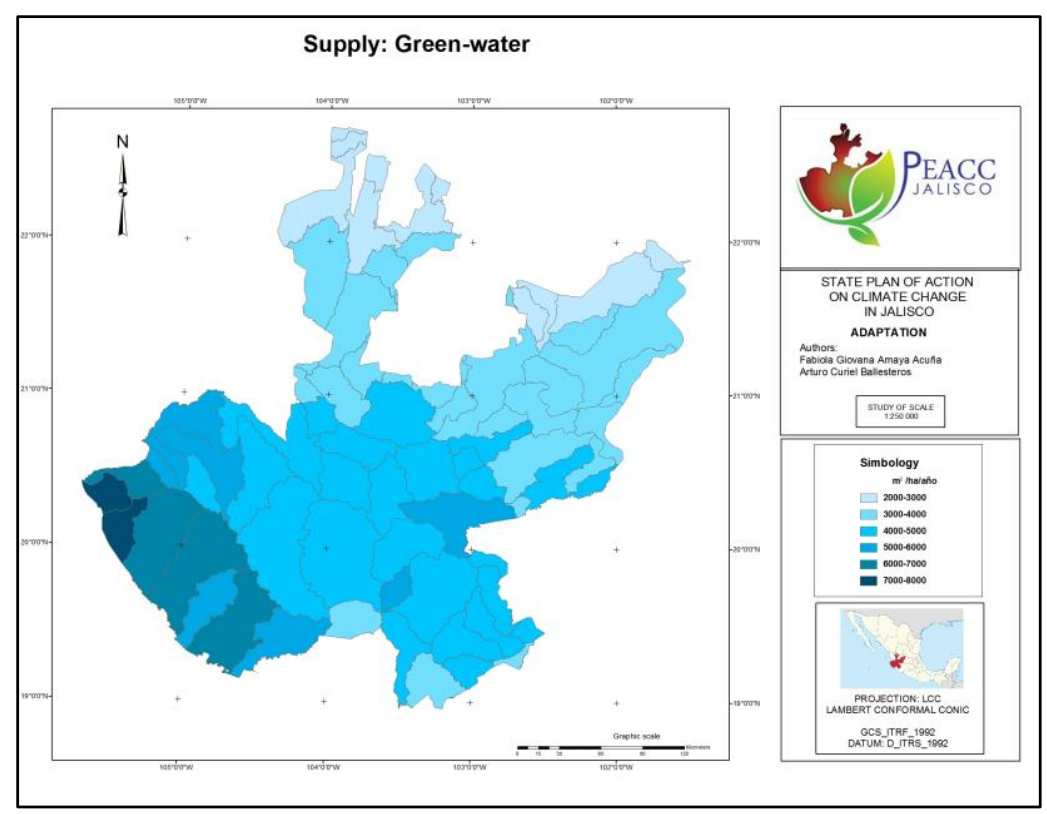

Figure 6. Green-water $\left(\mathrm{m}^{3}\right)$.

Blue-water supply.

The greatest blue-water supply, over $4000 \mathrm{Mm}^{3} /$ year, is found in the Lake Chapala subwatershed, shown on Figure 7 in the darkest blue color. It is followed by the R. Tomatlán, R. Verde-P.Santa Rosa and R. Ayuquila subwatersheds, which have a significant supply thanks to their hydraulic infrastructure for water storage; in addition to this surface-water supply, the accumulated groundwater recharge in the latter two subwatersheds is an important water source in establishing inclusion in this high supply category.

With respect to groundwater recharge, the R. de los Lagos watershed shows the highest levels, over $200 \mathrm{Mm}^{3} /$ year. 


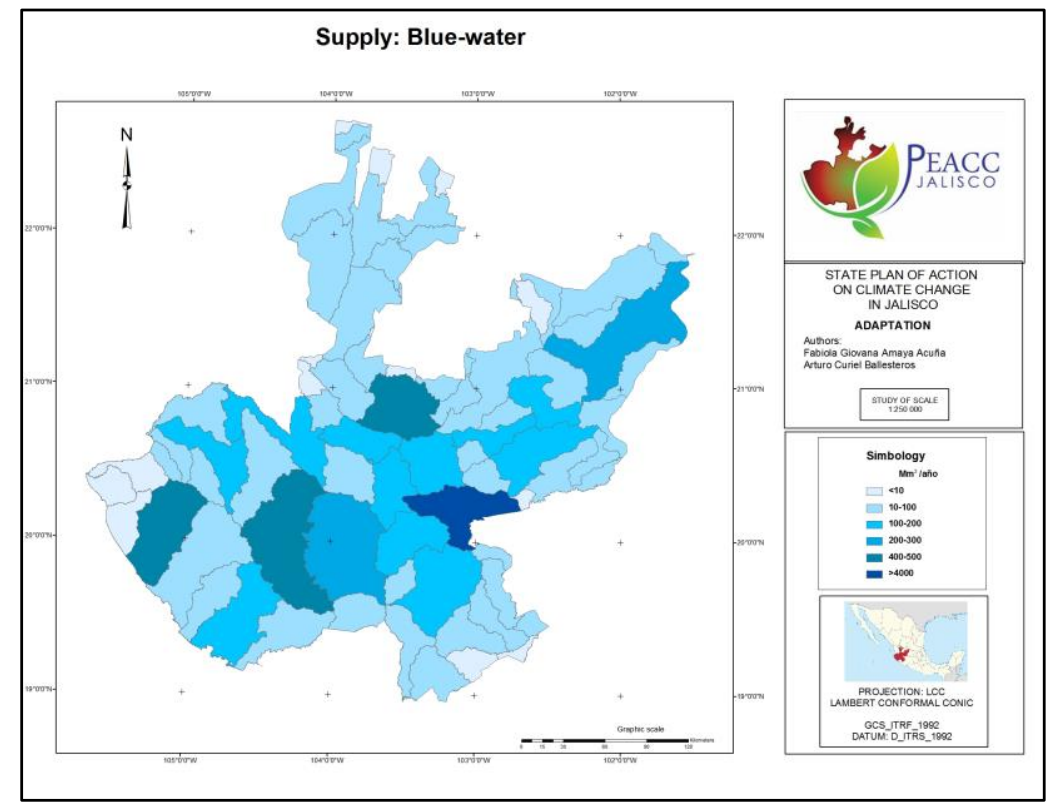

Figure 7. Blue-water $\left(\mathrm{Mm}^{3}\right)$.

\section{Hydrologic vulnerability in Jalisco.}

The results are grouped into eight categories, with darker colors representing the most vulnerable regions. The subwatersheds included in the three most- severe categories are found in the Altos Norte region, where the irrigated farming of corn and cowmilk production create a strong demand that is not offset by a sufficient water supply (Fig 8).

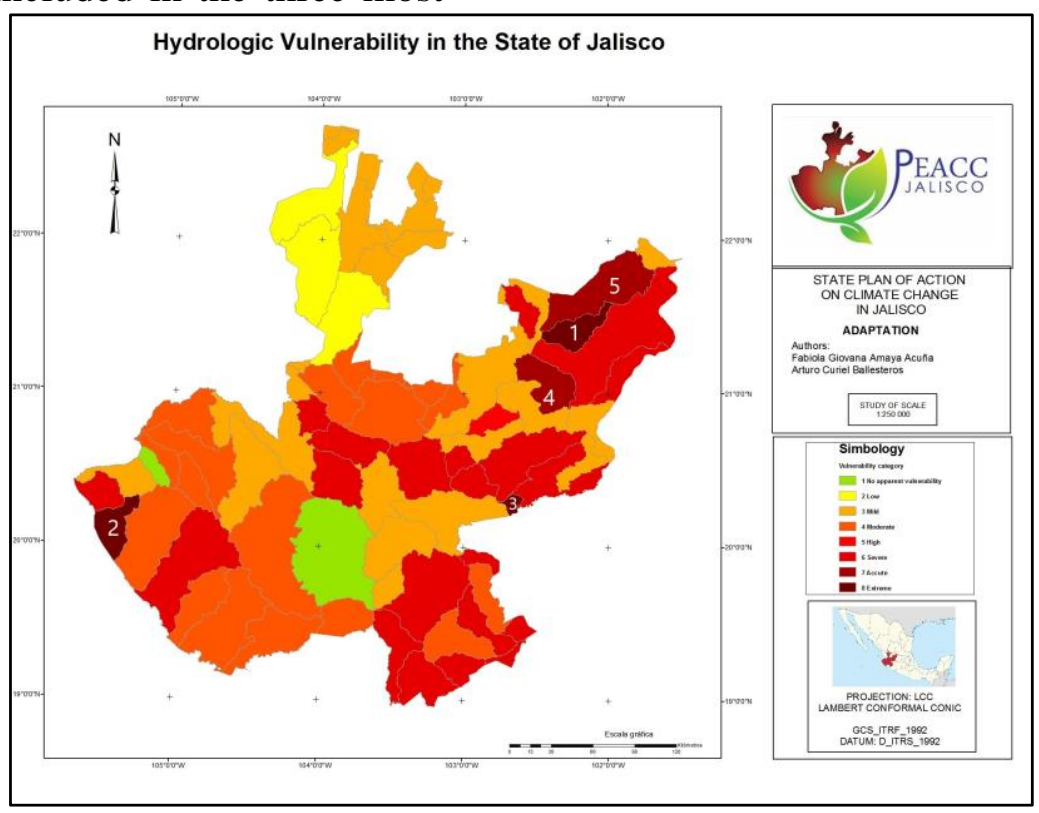

Figure 8. Hydrologic Vulnerability in the State of Jalisco.

The five subwatersheds in the two most critical categories are: R. Grande (1), R. Mismaloya (2) and R. Briseñas-L. Chapala
(3), classified as having extreme vulnerability, and R. San Miguel (4) and R. Encarnación (5), classified as accute. The 
data relating to supply and demand for

the following graphs: each of these subwatersheds is shown in

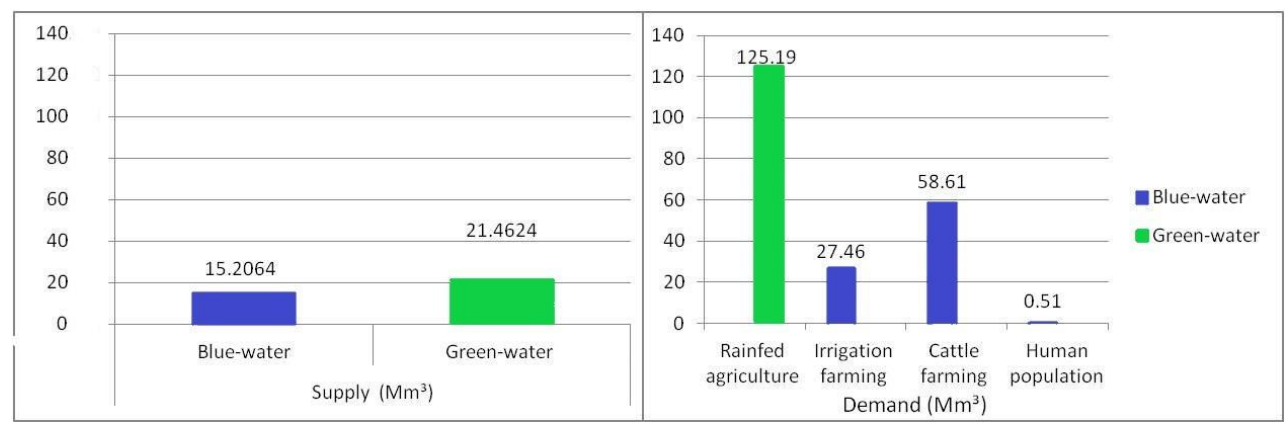

Figure 9. R. Grande.

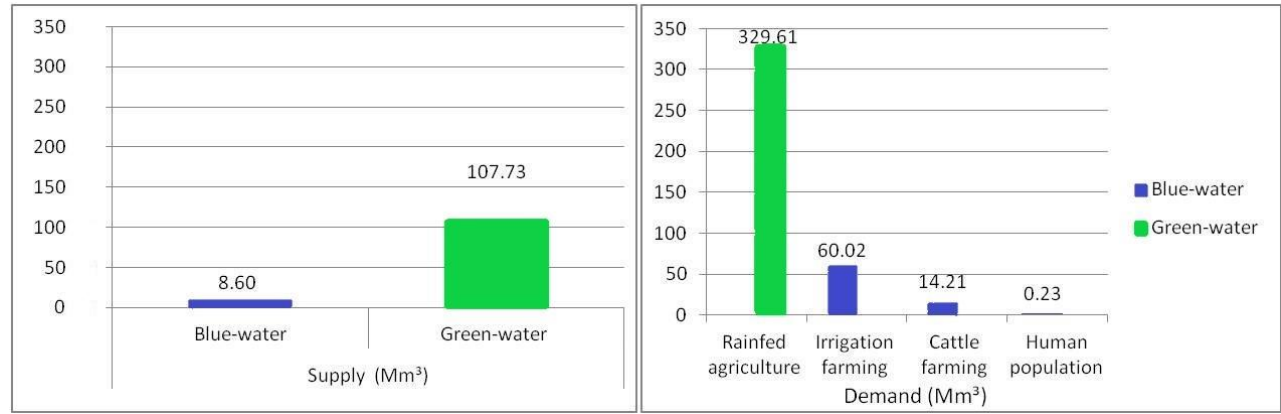

Figure 10. R. Mismaloya.

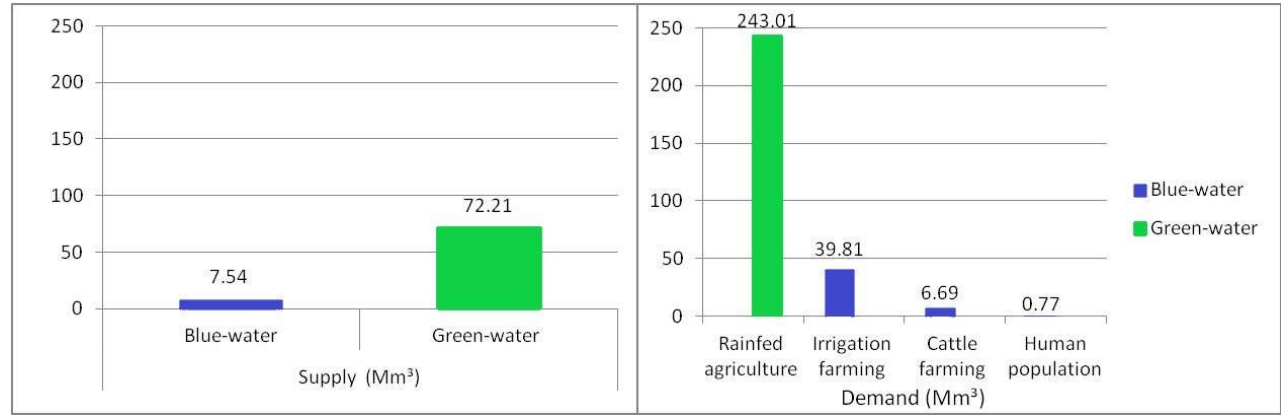

Figure 11. R. Briseñas-L. Chapala.

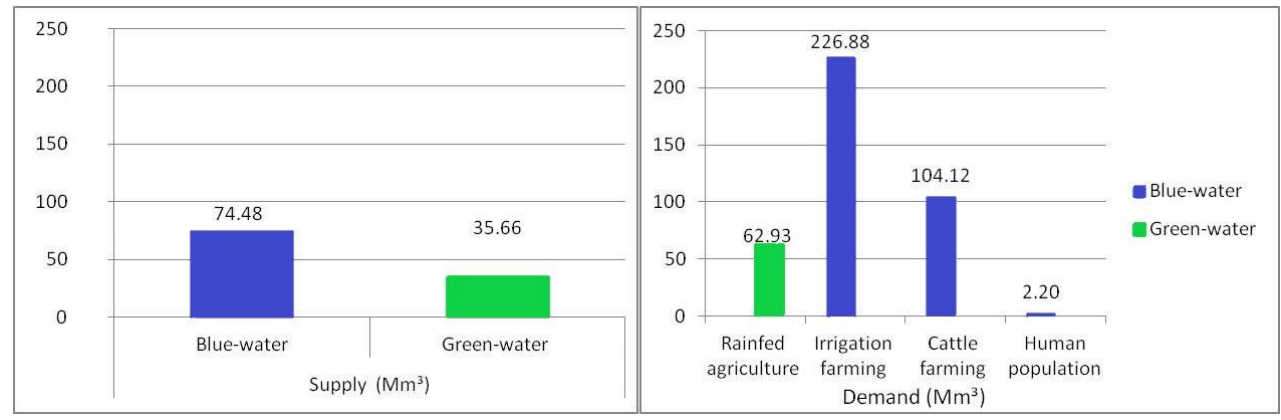

Figure 12. R. San Miguel. 


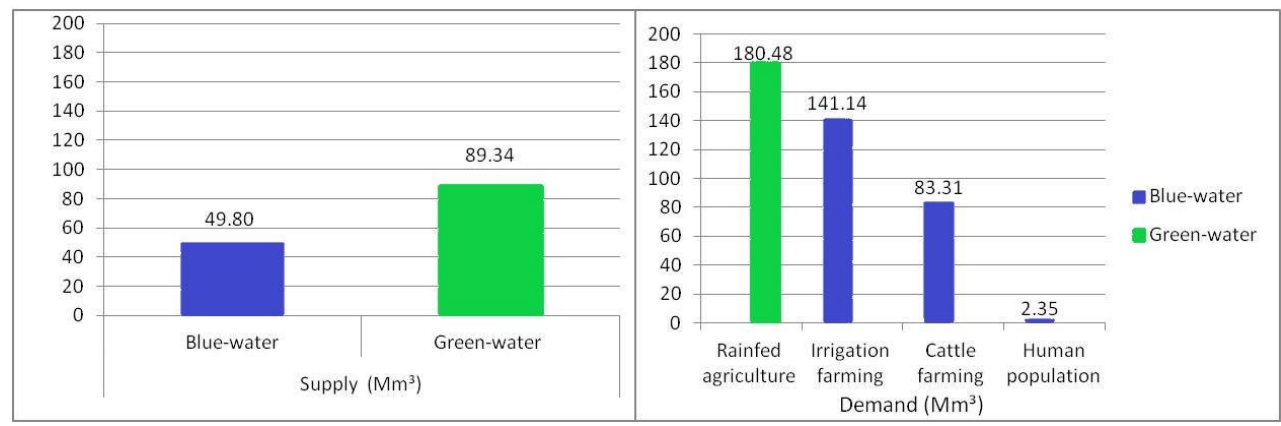

Figure 13. R. Encarnación.

\section{Discussion}

Jalisco, due to its size - approximately eight million hectares - is important both in the national and international context. The three hottest years recorded worldwide (NASA, 2014), have had an impact a year later, causing periods of drought lasting from 6 to 10 months. This means that Jalisco is not immune to climate anomalies, which are a risk in terms of meteorological, agricultural and hydrological drought (Wilhite et al. 2005). Nevertheless, perhaps the most-important type of drought that must be considered in Jalisco is the so-called socioeconomic drought, which is the result of the loss of the balance in water demand and supply within the territory analyzed in this paper. An area which must be prioritized, where most types of drought occur, is the Los Altos region, adjacent to Mexico's semiarid zone and which is today a major maize-growing region, where we find the country's "dairy basin", as well as Lagos de Moreno, one of the fastest-growing cities in the state.

\section{Conclusion}

The Altos Norte region in Jalisco, Mexico, must be a priority for climate change adaptation measures, as it exhibits the highest surface water stress. This situation becomes increasingly important when we consider it is the country's number one dairy producer. Research on adaptation measures to reduce hydrological vulnerability and increase resilience to climate change should be aimed at increasing the supply of water by means of mechanical, agricultural, technological innovation, cultural and political practices, which must lend equal importance to the restoration of ecosystem services; in addition, we must find ways to reduce pressure due to the demand for water resources from livestock and agricultural production and urban expansion, combining actions in the manufacturing sector, ecosystems and in public policy.

\section{References}

Cardona, O.D., Sarmiento, J.P. 1990. Vulnerability Analysis and Risk Assessment for the Health of population exposed to disasters. Colombian Red Cross Society (CRC). Colombia.

Colegio de Postgraduados, 1991. Soil and Water Conservation Handbook. México.

Comisión Estatal del Agua, Jalisco [CEA, JALISCO], 2013. State Water Information System (Sistema Estatal de Información del Agua). http://www.ceajalisco.gob.mx/sia/inde x_a.html (Accessed in April 2014).

Comisión Nacional del Agua [CONAGUA], 2012. Groundwater availability.

http://www.conagua.gob.mx/disponibi 
lidad.aspx $? \mathrm{n} 1=3 \& \mathrm{n} 2=62 \& \mathrm{n} 3=112$

(Accessed in April 2014).

Gobierno del Estado de Jalisco, 2017. Jalisco Gigante Agroalimentario, Desarrollo Económico y Bienestar. https://sader.jalisco.gob.mx/sites/sader.jalis co.gob.mx/files/jalisco_gigante_agroalime ntario_2017.pdf (Accessed in May 2020).

Halffter, G. (2003). Biogeografía de la entomofauna de montaña de México y América

Central, En: J. J. Morrone \& J. Llorente Bousquets (eds.). Una perspectiva latinoamericana de la biogeografía (págs.87-97). México: Las Prensas de Ciencias,

Facultad de Ciencias, UNAM.

Horton, R. 1945. Erosial Development of Streams and Their Drainage Basins: Hydrophysical Approach to Quantitative Morphology. Geol. Soc. Amer. Bull., 56, pages. 275-370.

Instituto Nacional de Ecología y Cambio Climático [INECC] (2012). Quinta Comunicación Nacional ante la Convención Marco de las Naciones Unidas sobre el Cambio Climático. México: Grupo Communicare, S. C.

Instituto Nacional de Estadística y Geografía [INEGI], 2010. Tell me... information per entity.

http://cuentame.inegi.org.mx/monografias/i nformacion/jal/poblacion/default.aspx?tem $\mathrm{a}=\mathrm{me} \& \mathrm{e}=14$ (Accessed in April 2014).

Instituto Nacional de Estadística y Geografía [INEGI]. 2012. Water Flow Simulator of Watersheds (SIATL). http://antares.inegi.org.mx/analisis/red_hid ro/SIATL/\# (Accessed in April 2014).

Jalisco State Land Information System [IITEJ]. 2012.

http://iit.app.jalisco.gob.mx/organismo/terr itorial.html (Accessed in April 2014).

Mekonnen, M. M. \& A. Y. Hoekstra, 2012. A Global Assessment of the Water Footprint of Farm Animal Products. Ecosystems, 15(3): 401-415.

Mendoza, L. S., 2012. Metropolitan water uses. http://redissa.hostei.com/congreso_2012/M endoza_Bohne.pdf
National Aeronautics and Space Administration [NASA], 2014. NASA Finds 2013 Sustained Long-Term Climate Warming Trend. http://www.nasa.gov/content/goddard/nas a-finds-2013-sustained-long-termclimate-warming-trend/\#.U0yC31WSySp (Accessed in April 2014)

Ruíz C., J.A., I.J. Gonzalez A., R. Regalado R., J. Anguiano C. \& I. Vizcaíno V. (2003). Edaphoclimatic resources for the productive sector in the state of Jalisco. Technical Paper No. 2. INIFAPCIRPAC. México. 278 p.

Wilhite, D.A. \& Buchanan-Smith M. 2005. Drought as Hazard: Understanding the Natural and Social Context. In: Wilhite, D.A. (Ed). Drought and Water Crises; Science, Technology, and Management Issues. Taylor \&Francis Boca Raton.

World Health Organization [WHO], 2003. The Right to water. Health and human rights publication series; no. 3. ISBN: 9241590564. 